\title{
DC Home Appliances for DC Distribution System
}

\author{
MUHAMMAD KAMRAN*, MUHAMMAD BILAL*, AND MUHAMMAD MUDASSAR** \\ RECEIVED ON 11.07.2016 ACCEPTED ON 22.11.2016
}

\begin{abstract}
This paper strengthens the idea of DC distribution system for DC microgrid consisting of a building of 50 apartments. Since the war of currents AC system has been dominant because of the paucity of research in the protection of the DC system. Now with the advance research in power electronics material and components, generation of electricity is inherently DC as by solar PV, fuel cell and thermoelectric generator that eliminates the rectification process. Transformers are replaced by the power electronics buck-boost converters. DC circuit breakers have solved the protection problems for both DC transmission and distribution system. In this paper $308 \mathrm{~V}$ DC microgrid is proposed and home appliances (DC internal) are modified to operate on 48V DC from DC distribution line. Instead of using universal and induction motors in rotary appliances, BLDC (Brushless DC) motors are proposed that are highly efficient with minimum electro-mechanical and no commutation losses. Proposed DC system reduces the power conversion stages, hence diminishes the associated power losses and standby losses that boost the overall system efficiency. So in view of all this a conventional AC system can be replaced by a DC system that has many advantages by cost as well as by performance.
\end{abstract}

Key Words: DC Micro Grid, DC Appliances, Brushless DC Motors.

\section{INTRODUCTION}

$\mathrm{I}$

$n$ late the 1880s, the war between two rivals in favor of $\mathrm{AC}$ and DC power was won by the AC because of emissions coexist with the generation of AC by traditional dominant fossil fuels that seriously not only balancing out the earth environment but may also be a cause of the extinction of earth species. In DC distribution system with DC sources and DC appliances, 47\% energy saving is observed by Gholase and Fernandes [1] and 22\% system efficiency is improved by Anand and Fernandes [2]. In this paper system efficiency is improved by removing conversion stages and replacing induction motors with efficient BLDC motors. Keeping an eye over the present rate of research on DC, future is pro to DC technology. A typical DC distribution system is shown in Fig. 1. Such stand-alone DC distribution systems are flexible enough to integrate with other distributed generations [3].

Most appliances work internally on DC power; they take $\mathrm{AC}$ as input and after conversion process bring the required DC voltage level. Garbesi et. al. [4] 33\% energy

Corresponding Author (E-Mail: engr.kamran09004@gmail.com)

* $\quad$ Center for Energy Research \& Development, University of Engineering \& Technology, Lahore.

** School of Electrical Engineering, The University of Faisalabad, Faisalabad.

Mehran University Research Journal of Engineering \& Technology, Volume 36, No. 4, October, 2017 [p-ISSN: 0254-7821, e-ISSN: 2413-7219] 
saving is estimated by replacing standard technology with the DC internal efficient appliances and a further $14 \%$ by operating DC internals on direct DC. These DC internal appliances take AC as input followed by AC/DC converter. This conversion process creates heat losses both in working mode and standby mode. If these appliances are fed with solar PV power, transformer and rectifier would be terminated from the circuit [5] that saves a considerable amount of energy [6].

The absence of skin effect in DC system [7] reduces the material cost of the wiring as the whole cross section carries the current. The overall cost of the system is greatly reduced as the equipment for the power factor improvement, $\mathrm{AC} / \mathrm{DC}$ and $\mathrm{DC} / \mathrm{AC}$ conversion and reactive power compensation is not required in DC distribution system [8]. Enhanced energy savings and improved

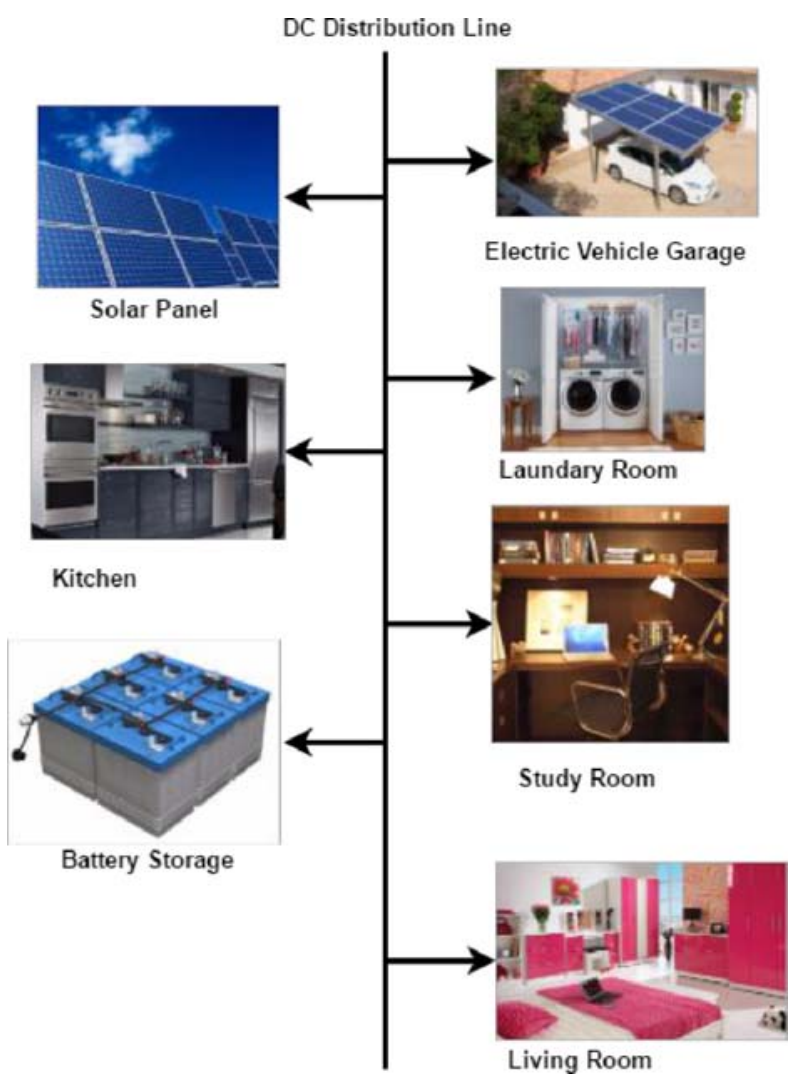

FIG. 1. SHOWING THE LAYOUT OF DC DISTRIBUTION SYSTEM reliability by DC distribution system is recommended by Vagelis et. al. [9]. Soo and Jung [10] have studied the efficiency of the DC distribution system by using multiple DGs (Distributed Generations) while Kamran et. al. [11] has studied MPPT based DC-DC buck-boost converter for multiple DGs.

With the advancement in semiconductor materials and devices DC can directly be generated by using solar PV cell. Solar PV cell generates clean and green renewable energy. Historically, this energy is either stored in batteries or delivered to the AC grid through inverters that brings major conversion losses.

\section{EFFICIENCY IMPROVEMENT OF DC SYSTEM}

The efficiency of a DC distribution system depends upon the losses in the cables and conversion losses (power electronics + electro-mechanical conversion stage) as given by Equation (1).

$\mathrm{P}_{\text {loses }}=\mathrm{P}_{\text {cables }}+\mathrm{P}_{\text {converter }}+\mathrm{P}_{\text {mechanical }}$

$\mathrm{P}_{\text {cables }}$ are the losses occurring in the distribution cables. They depend upon the voltage level of the distribution line. In this paper $308 \mathrm{~V}$ DC, the peak value of $220 \mathrm{~V} \mathrm{AC}$, is selected as a distribution line voltage since the voltage level below this increases the losses in cables as given in Table 1 calculated by Equation (2) [12].

$$
\mathrm{P}_{\text {cables }}=\left(2 \cdot \frac{\rho}{\mathrm{A}}\right)\left(\frac{\mathrm{P}}{\eta \cdot \mathrm{NV} \mathrm{DC}_{\mathrm{DC}}}\right)^{2} \cdot 2 \mathrm{l}\left(\frac{\mathrm{N}^{2}+2 \mathrm{~N}+2}{6}\right)
$$

TABLE 1. LOSSES AT DIFFERENT VOLTAGE LEVELS

\begin{tabular}{|c|c|}
\hline Voltage (V) & Losses (W) \\
\hline 308 & 17.19 \\
\hline 220 & 33.7 \\
\hline 110 & 134 \\
\hline 48 & 708 \\
\hline
\end{tabular}

Mehran University Research Journal of Engineering \& Technology, Volume 36, No. 4, October, 2017 [p-ISSN: 0254-7821, e-ISSN: 2413-7219] 
Where $\rho$ is the electrical resistivity ( $\left.2 \times 10^{-8} \Omega . m\right)$, A is the $\mathrm{X}$-sectional area of cable $\left(60 \mathrm{~mm}^{2}\right), 1$ is the total length of the cable (200m), P is the total power that load absorbs (100 W assumption for each apartment), $\eta$ is the converter efficiency (85\% assumed), $\mathrm{V}_{\mathrm{DC}}$ is the DC distribution line voltage level, $\mathrm{N}$ is the number of apartments in the building that is assumed 50 in this paper.

$\mathrm{P}_{\text {converter }}$ are the losses that occur in the converter. They are in inverse relation with the efficiency of the converter as given in Equation (3) [12].

$\mathrm{P}_{\text {converter }}=\left(\frac{1}{\eta}\right) \mathrm{P}$

Efficiency ( $\eta$ ) of the DC-DC converter is higher than DCAC-DC because of the double conversion in the latter converter [13]. This is one of the reasons that DC home appliances operated on DC from DC distribution line are proposed here.

$\mathrm{P}_{\text {mechanical }}$ are the losses that occur in the conversion of electrical power into mechanical power as in motors. DC motors and 1- $\theta$ induction motors are not efficient enough to boost the efficiency of the proposed DC distribution system. Replacement of these motors with the BLDC motors is proposed in this paper.

\section{DC HOME APPLIANCES}

Not all but most of the home appliances internally operate on DC that is obtained after a transformer and a rectifier constituting a major part of the power losses. Anand and Fernandes [2] stated a 22\% reduction in resources if we use DC than conventional AC for residential loads and it is safe and sound for human even in direct touch. This portion discusses the modified 48V DC appliances in which transformer and rectifier are replaced by a DC-DC power electronics converter. These modified appliances are more efficient than traditional AC fed appliances.

\subsection{Appliances with Motors}

Most of the appliances having rotatory part use universal dc motors or 1- $\theta$ induction motors which have low efficiency because of carbon brush and mechanical commutation bearing a major maintenance cost and mechanical losses. All such motors can be replaced with BLDC which has a high efficiency, low noise [14], low power consumption and a wide range of speed.

In BLDC motor permanent magnet acts as a rotor while 3- $\theta$ DC supply is given to the static stator coil. There is low stator and rotor air gap which increases the efficiency by increasing the magnetic torque on the rotor by the stator. So no need of carbon brushes to supply the current which makes it maintenance free. But because of the presence of magnet, electronics and sensor, BLDC motor is costly than induction and universal motor [15]. With the adoption of DC grid and BLDC motor in industrial and residential appliances, the cost will definitely be reduced in future.

\subsubsection{Air Conditioner}

Conventional air conditioning units use either $1-\theta$ induction motor or universal motor for compressor, swing and blower fans. They are fed with 220V AC and also carry some AC-DC conversion for low voltage applications as shown in Fig. 2.

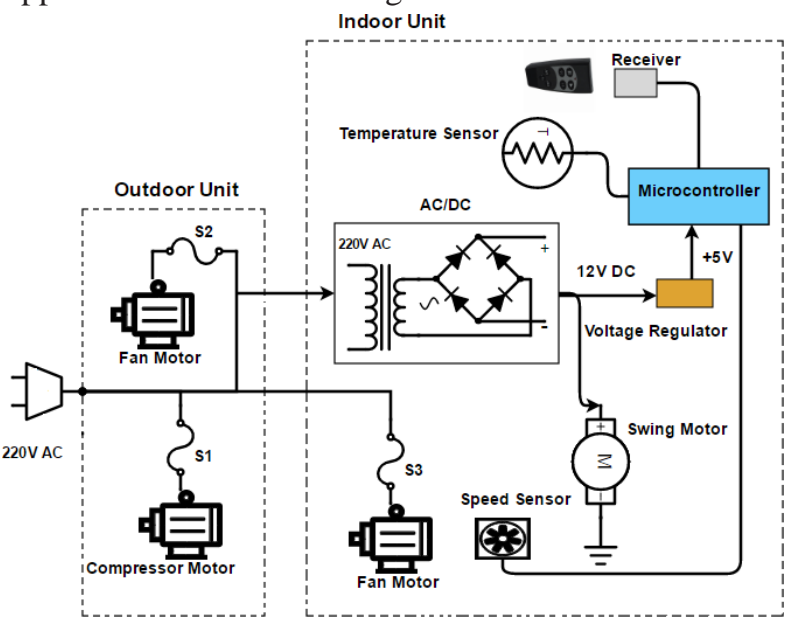

FIG. 2. CURRENT AIR CONDITIONER CIRCUIT

Mehran University Research Journal of Engineering \& Technology, Volume 36, No. 4, October, 2017 [p-ISSN: 0254-7821, e-ISSN: 2413-7219] 
DC operated air conditioning units are available for automobiles that use DC compressors, DC blower fan motor and DC swing motor. In the proposed system these DC motors are replaced with BLDC motors and the AC-DC converter is replaced by the DC-DC converter. The outdoor unit takes $48 \mathrm{~V}$ input for itself and the indoor unit's swing BLDC motor, blower fan BLDC motor and control unit. The use of BLDC motors for indoor and outdoor units reduces the noise level and energy consumption. Solar $48 \mathrm{~V}$ AC is available by green energy innovations and hotspot energy [16,17] which can be operated on the proposed DC distribution system with the incorporation of a DC-DC converter. The proposed BLDC motor based DC operated air conditioner is depicted in Fig. 3.

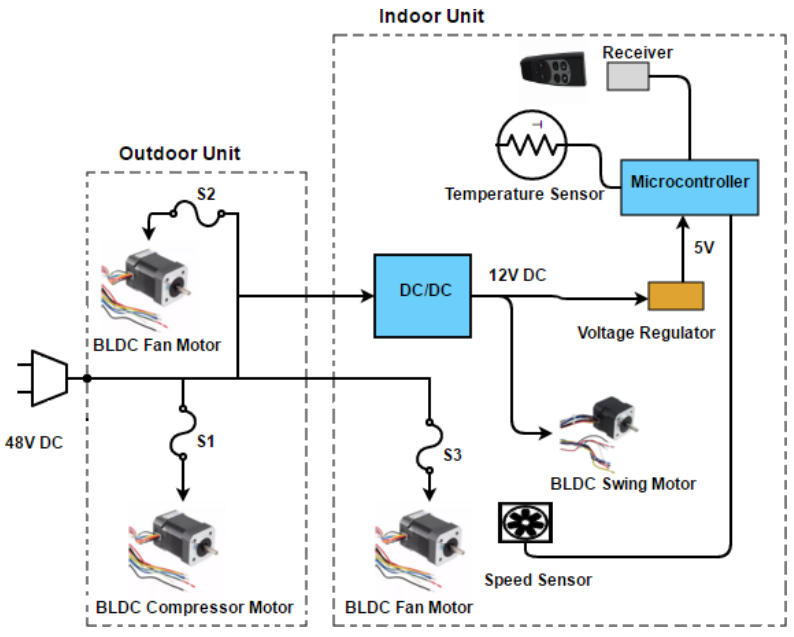

FIG. 3. FLOW DIAGRAM OF DC AIR CONDITIONER CIRCUIT

\subsubsection{Microwave Oven}

Microwave oven consists of two sections with separate independent circuits and power supplies. HVS (High Voltage Section) and LVS (Low Voltage Section). HVS contains magnetron whose power supply consists of a high voltage transformer followed by a voltage doubler. While LVS contains turntable motor, magnetron fan motor (1- $\theta$ induction motor) [18] and switching device. In AC operated microwave oven $220 \mathrm{~V}$ from input AC source is supplied to the turntable and magnetron fan motor as shown in Fig. 4. In some modified ones, the $220 \mathrm{~V}$ is stepped down to operate a $21 \mathrm{~V}$ turntable AC motor that reduces manufacturing cost and power consumption [19].

In DC microwave oven input AC is rectified into DC using transformer and rectifier to run turntable DC motor, magnetron fan motor, lamp and switching device. Output DC voltage is inverted into AC and boosted by a transformer and again converted into DC to supply to the magnetron [20] as shown in Fig. 5.

In proposed DC microwave oven input is taken directly from a DC distribution line which in low voltage section drives the BLDC turntable motor, BLDC magnetron fan motor, DC lamp and a switching device. In HVS it is boosted by using a flyback converter and supplied to the magnetron as shown in Fig. 6. In this method conversion losses, mechanical losses and noise are greatly reduced and a high efficiency is achieved.

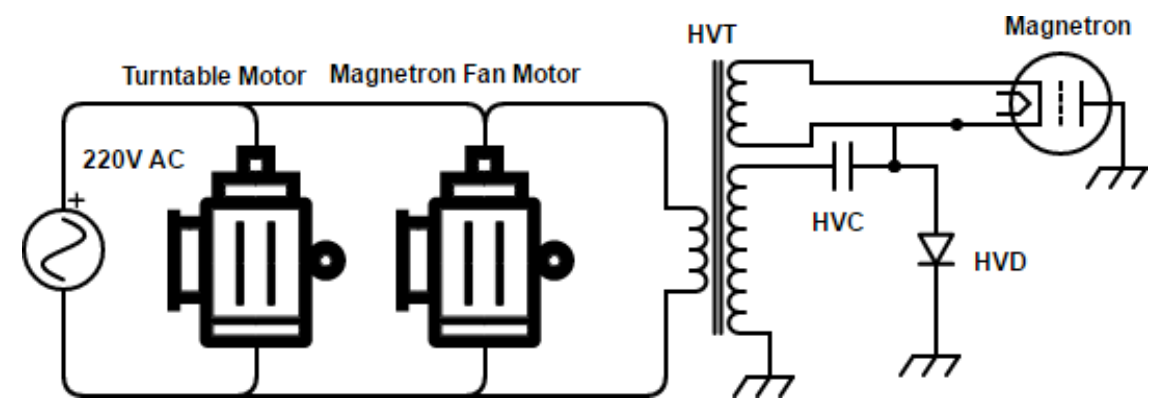

FIG. 4. AC MICROWAVE OVEN 


\subsubsection{Fans}

Current ceiling, table and bracket fans use 1- $\theta$ induction motors which are heavy and inefficient with 50\% efficiency [21]. Fans with DC motors take DC power after transformation and rectification of the commercially available 220V AC. These DC motors bear friction losses and brushes maintenance cost making it inefficient. Future DC fans will be popular with BLDC motors taking DC input directly from the proposed DC distribution line. Fans with BLDC motors use $50 \%$ less power which can further be reduced by improving the aerodynamics of the blades [22]. Desroches and Garbesi estimated an efficiency of 90\% with 75W BLDC fan and 75\% efficiency with 75W AC induction motor [23]. These fans would be highly efficient with minimum conversion losses.

\subsubsection{Cloth Washer}

Most of the cloth washers available in markets incorporate 1- $\theta$ induction motors. They use transformer and rectification process to obtain a DC lowlevel voltage to operate the control circuit. Fisher and Paykel have some models that use BLDC motors but incorporate a rectifier. In lieu of using AC power followed by transformer and rectifier, DC input from a DC distributed line is proposed to operate BLDC motor and control circuit of the washing machine and dryer.

\subsubsection{Water Pump}

Current home water pumps use a 1- $\theta$ induction motor operated on 220V AC. In solar DC water pumps for flood irrigation an inverter is used to run $1-\theta$ induction motor.

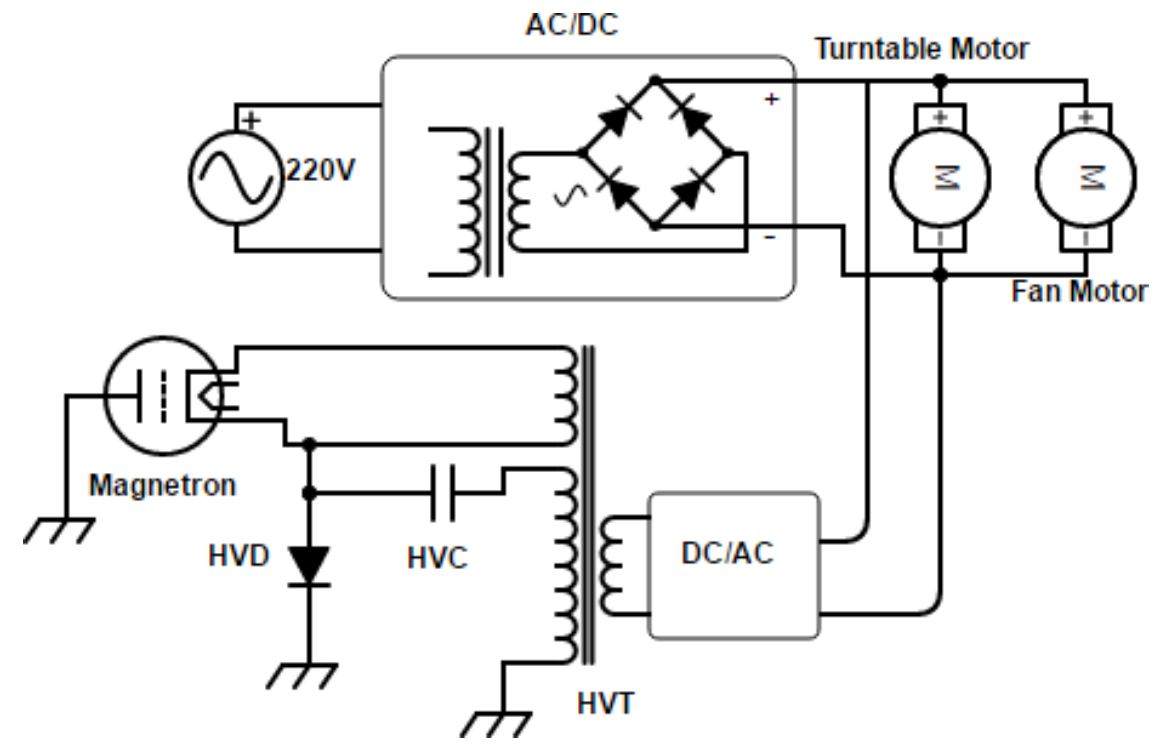

FIG. 5. DC MICROWAVE OVEN

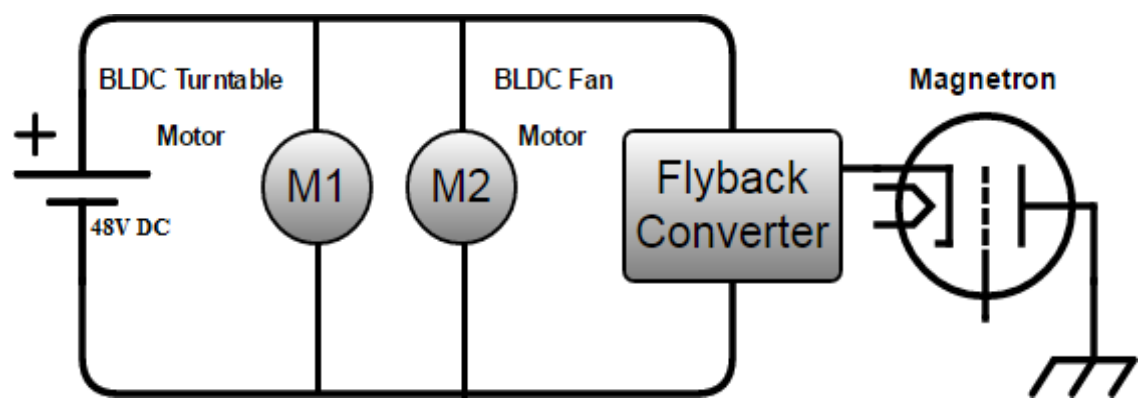

FIG. 6. PROPOSED DC MICROWAVE OVEN

Mehran University Research Journal of Engineering \& Technology, Volume 36, No. 4, October, 2017 [p-ISSN: 0254-7821, e-ISSN: 2413-7219] 
This water pump can be modified into an efficient one by replacing induction motor with BLDC motor operated on $48 \mathrm{~V}$ from DC distribution line. Some 12V BLDC pumps with low flow rate are available in the market for drip irrigation, system. Rajan et. al. [24] has proposed an MPPT based DC-DC buck-boost converter to operate a BLDC water pump from solar PV.

\subsubsection{Refrigerator}

Current home refrigerators use 1- $\theta$ induction motor compressor. In market 12 and 24V BLDC compressors by Zhejiang Boyard are available for mobile freezers and car/ truck air conditioners. They can be used in home refrigerators and $48 \mathrm{~V}$ BLDC compressor is also available for heavy applications. Such refrigerators can be operated at $48 \mathrm{~V}$ from DC distribution line proposed here. The universal motor used for condenser fan motor is also replaced with BLDC fan motor. The replacement of AC motors with BLDC terminates most of the conversion stages improving system efficiency.

\subsubsection{Air Cooler}

In air cooler 3 motors are used. 1- $\theta$ induction pump motor, $1-\theta$ induction fan motor and a swing motor. In proposed air cooler all these motors are replaced with BLDC motor. In solar air cooler DC power is inverted to AC which is eliminated in the proposed system.
Various appliances like automatic door system, dish washer and mixer grinder running with DC motors are available in the market that need only the replacement of universal motor with BLDC motor and AC/DC converter with DC/DC. In [1] a DC operated BLDC mixer grinder is proposed with the efficiency of $>80 \%$. While the current universal motor grinder has an efficiency of $43 \%$ only.

\subsection{Electronics Appliances}

Laptop computer, TVs, security cameras and data centers are the major electronics load which can be made efficient or even energy star just by replacing input AC/DC converter with the buck-boost converter.

\subsubsection{Laptop}

In current laptop adapter, 220V AC is taken from the distribution line. After stepping it down and rectification process it is decided by the switching technique whether to charge the battery or run the laptop or both. Using buck converter the output 19V DC is reduced to 5, 3.3, 2 and $1.5 \mathrm{~V}$ for various components to operate. The power architecture is shown in Fig. 7.

In proposed scheme input is directly taken from 48V DC distribution line followed by a buck converter with the $19 \mathrm{~V}$ output. Hence this proposed DC adapter is much efficient than current AC adapter as major power conversion losses are eliminated in proposed architecture as shown in Fig. 8.

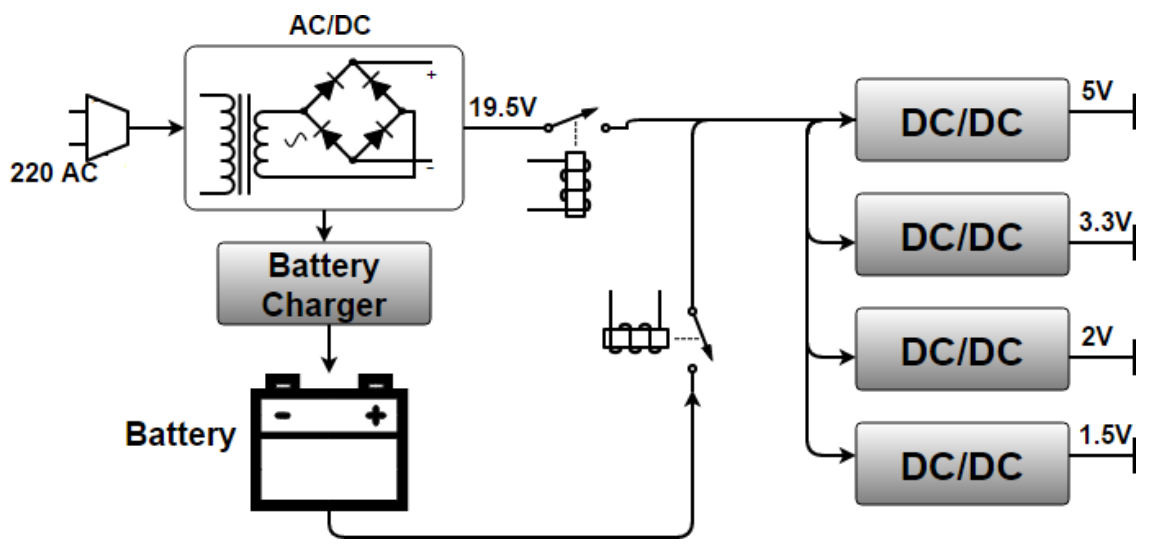

FIG. 7. CURRENT LAPTOP POWER ARCHITECTURE 


\subsubsection{Lights}

Until now incandescent lights are widely used in residential areas. These are highly inefficient because of their resistive nature. Compact Fluorescent CFL replaced the incandescent light because of high efficiency. The reason of inefficiency is again the power conversion stage from AC-DC and old technology. LED (Light-Emitting Diode) lights are the most efficient one with low energy consumption and long operating life. They best work on the DC distribution system resulting highly efficient. LED converts $80 \%$ of the input energy into light as compared to $10 \%$ of the incandescent bulbs [25]. Table 2 shows that LED consumes less power as compared to old technologies and average life is much larger.

\subsubsection{LED television}

In AC fed LED TVs, input AC is passed through EMI filter, transformer followed by a rectification stage and a PFC (Power Factor Correction) stage to take the input line PF close to unity. A DC-DC flyback converter is used to operate CCFL and standby power stage shown in Fig. 9. These conversion losses can be eliminated if LED TVs are operated directly on DC distribution line as shown in Fig. 10.

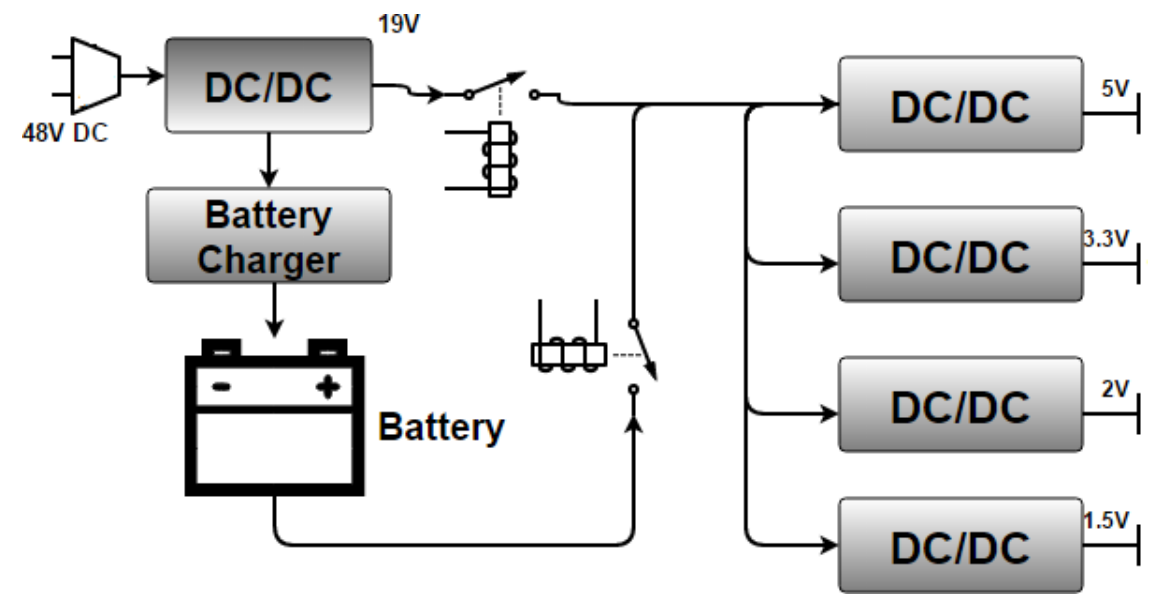

FIG. 8. PROPOSED LAPTOP POWER SCHEME

TABLE 2. COMPARISON OF LIGHT TECHNOLOGIES [19]

\begin{tabular}{|c|c|c|c|}
\hline & Incandescent & CFLs & LEDs \\
\hline Watts Consumed & 75 & 20 & 16.5 \\
\hline Average Life (hours) & 1000 & 10,000 & $25000-35000$ \\
\hline Average Cost/bulb \$ & 0.50 & 5 & $25-100$ \\
\hline Operating Cost/yr \$ & 8.87 & 2.37 & 1.95 \\
\hline
\end{tabular}

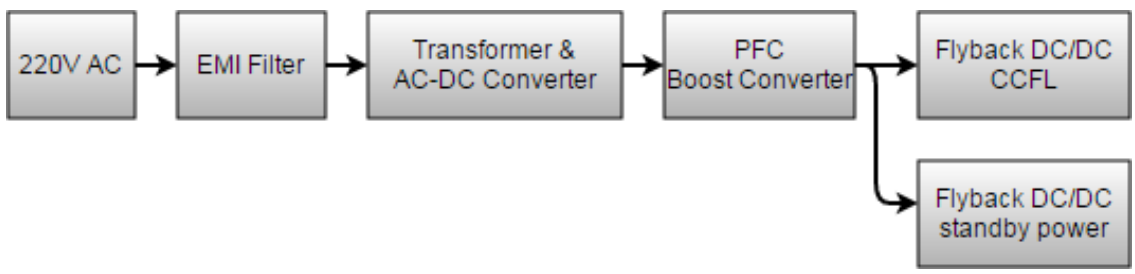

FIG. 9. AC OPERATED DC INTERNAL LED TELEVISION

Mehran University Research Journal of Engineering \& Technology, Volume 36, No. 4, October, 2017 [p-ISSN: 0254-7821, e-ISSN: 2413-7219] 
The power consumption of different television technologies of different screen sizes is given in Table 3. From Table 3 it is obvious that LED TV is the most efficient one which can further be improved by excluding rectification stage proposed in Fig. 10.

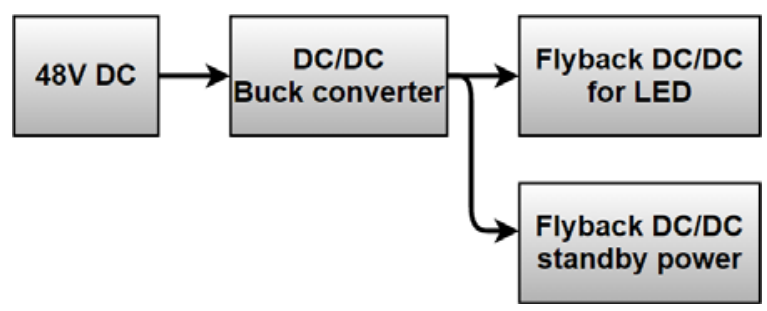

FIG. 10. DC OPERATED LED TELEVISION

TABLE 3. POWER RATINGS OF DIFFERENT TV TECHNOLOGIES [26]

\begin{tabular}{|c|c|c|c|}
\hline Screen Size (Inch) & LED & LCD & CRT \\
\hline 15 & 15 & 18 & 65 \\
\hline 17 & 18 & 20 & 75 \\
\hline 19 & 20 & 22 & 80 \\
\hline 20 & 24 & 26 & 90 \\
\hline 21 & 26 & 30 & 100 \\
\hline 22 & 30 & 40 & 110 \\
\hline 24 & 40 & 50 & 120 \\
\hline 30 & 50 & 60 & - \\
\hline 34 & 55 & 70 & - \\
\hline
\end{tabular}

\subsection{Reduction in Power Consumption}

In order to estimate the energy savings by adopting a DC distribution system, power ratings of different home internally DC appliances taking AC as input are collected from [4]. AC-DC power conversion losses are calculated by using Equation (3). Then a load profile for a family of 3 members for a month is calculated using calculator [27] and it is observed that $65.4 \mathrm{kWh} / \mathrm{month} /$ home energy can be saved if the internally DC appliances are operated directly on DC as shown in Table 4.

The other advantage of removing AC-DC converter is the savings of standby electricity which is consumed even the device is switched off but still plugged in standby power of different appliances is given in Table 5 [18] and it is estimated that $22.6 \mathrm{kWh} / \mathrm{month} /$ home energy can be saved by the proposed DC home appliances in this paper.

Efficiencies of different AC and BLDC motors for various home appliances are collected from $[1,21,22,28]$ and it is estimated that an overall $24 \%$ efficiency of the system is improved by replacing AC motors with BLDC motors shown in Table 6.

TABLE 4. ENERGY SAVINGS AVAILABLE IN CONVERSION STAGES

\begin{tabular}{|c|c|c|c|c|c|c|c|}
\hline Appliances & $\begin{array}{c}\text { DC Internal } \\
\text { Power } \\
(\mathrm{W})\end{array}$ & $\begin{array}{c}\text { Conversion } \\
\text { Efficiency } \\
\text { AC/DC }\end{array}$ & $\begin{array}{c}\text { Conversion } \\
\text { Losses (W) } \\
\text { AC/DC }\end{array}$ & Quantity & $\begin{array}{c}\text { Working } \\
\text { Hours }\end{array}$ & $\begin{array}{c}\text { DC } \\
\text { Internal }\end{array}$ & $\begin{array}{c}\text { Direct DC } \\
(\mathrm{kWh})\end{array}$ \\
\hline Ceiling Fan & 88 & 0.87 & 13 & 3 & 180 & 54.5 & 47.5 \\
\hline Room AC & 1900 & 0.89 & 235 & 1 & 90 & 192 & 171 \\
\hline Clothe Washer & 350 & 0.87 & 52 & 1 & 6 & 24 & 21 \\
\hline Coffee Makers & 900 & 0.87 & 134 & 1 & 4 & 4.1 & 3.6 \\
\hline Color TV & 175 & 0.85 & 31 & 1 & 12.36 & 10.50 \\
\hline Dishwashers & 1200 & 0.88 & 164 & 1 & 15 & 20.46 & 18 \\
\hline Clothes Dryers & 2790 & 0.89 & 345 & 1 & 2 & 6.27 & 5.58 \\
\hline space heater & 1000 & 0.89 & 124 & 1 & 60 & 67.44 & 60 \\
\hline Freezers & 540 & 0.87 & 80 & 1 & 720 & 44.64 & 38.88 \\
\hline Incandescent & 30 & 0.84 & 6 & 3 & 150 & 16.2 & 13.5 \\
\hline Microwave Oven & 750 & 0.87 & 112 & 1 & 5 & 4.31 & 3.75 \\
\hline Desktop & 74 & 0.82 & 16 & 1 & 60 & 5.4 & 4.44 \\
\hline Security System & 20 & 0.83 & 4 & 4 & 720 & 69.12 & 57.60 \\
\hline
\end{tabular}

Mehran University Research Journal of Engineering \& Technology, Volume 36, No. 4, October, 2017 [p-ISSN: 0254-7821, e-ISSN: 2413-7219] 
TABLE 5. STANDBY LOSSES OF APPLIANCES

\begin{tabular}{|c|c|c|}
\hline Appliances & $\begin{array}{c}\text { Average Standby } \\
(\mathrm{W})\end{array}$ & kWh \\
\hline Air Conditioner & 0.9 & 0.648 \\
\hline Mobile Charger & 0.26 & 0.187 \\
\hline CRT Monitor & 0.8 & 0.576 \\
\hline LCD Monitor & 1.13 & 0.814 \\
\hline Hub, USB & 1.44 & 1.03 \\
\hline Modem, DSL & 1.37 & 0.986 \\
\hline Laser Printer & 1.58 & 1.14 \\
\hline Scanner & 2.48 & 1.78 \\
\hline Security System & 2.7 & 1.94 \\
\hline Speakers & 1.79 & 1.29 \\
\hline CRT TV & 3.06 & 2.20 \\
\hline CD Player & 5.04 & 3.63 \\
\hline Coffee Maker & 1.14 & 0.821 \\
\hline Microwave Oven & 3.08 & 2.22 \\
\hline VCR & 4.68 & 3.37 \\
\hline Total & 31.45 & 22.6 \\
\hline
\end{tabular}

TABLE 6. EFFICIENCY COMPARISON OF AC AND BLDC MOTORS FOR HOME APPLIANCES

\begin{tabular}{|c|c|c|c|}
\hline \multirow{2}{*}{ Appliances } & AC & BLDC \\
\hline \multirow{2}{*}{ Microwave Oven } & Turntable Motor & 75 & 90 \\
\cline { 2 - 4 } & Fan Motor & 75 & 90 \\
\hline \multirow{3}{*}{ Air Conditioner } & Indoor Fan & 75 & 90 \\
\cline { 2 - 4 } & Outdoor Fan & 75 & 90 \\
\cline { 2 - 4 } & Compressor & 60 & 80 \\
\hline \multirow{2}{*}{ Refrigerator } & Compressor & 60 & 80 \\
\cline { 2 - 4 } & Condenser Fan & 75 & 90 \\
\hline \multirow{2}{*}{ Air Cooler } & Pump Motor & 75 & 91 \\
\cline { 2 - 4 } & Swing Motor & 75 & 90 \\
\cline { 2 - 4 } & Fan Motor & 75 & 90 \\
\hline Ceiling Fan & Fan Motor & 75 & 90 \\
\hline Water Pump & Pump Motor & 75 & 91 \\
\hline Elevator & Elevator Motor & 75 & 90 \\
\hline Dish Washer & Washer Motor & 75 & 90 \\
\hline Cloth Washer & Washer Motor & 75 & 90 \\
\hline Cloth Dryer & Dryer Motor & 75 & 90 \\
\hline Mixer Grinder & Grinder Motor & 43 & 80 \\
\hline Average Efficiency (\%) & & 71 & 88 \\
\hline
\end{tabular}

\section{CONCLUSION}

This paper investigates the energy savings by adopting DC distribution system instead of conventionally dominant AC distribution system. ADC microgrid of 308V is chosen as a distribution line voltage. Home appliances are modified by removing voltage transformation and rectification and replacing 1- $\theta$ IM with most efficient BLDC motors. This increases the efficiency of the appliances and makes them compatible with the DC distribution system. The removal of AC-DC conversion saves $65.4 \mathrm{kWh} / \mathrm{month} / \mathrm{home}$ energy from conversion losses and $22.6 \mathrm{kWh} / \mathrm{month} /$ home from standby losses. The replacement of AC motor with BLDC motor increases the overall efficiency of the system by $24 \%$. Therefore, 308V DC distribution system with DC efficient home appliances saves a handsome amount of energy and can be envisaged as a future DC grid.

\section{ACKNOWLEDGEMENT}

The authors pay special thanks to Dr. Hifsa Shahid, Department of Electrical Engineering, for her precious advice for this research work and to the Center for Energy Research \& Development University of Engineering \& Technology, Lahore, Pakistan, where this research was conducted.

\section{REFERENCES}

[1] Gholase, V., and Fernandes, B.G., "Design of Efficient BLDC Motor for DC Operated Mixer-Grinder”, IEEE International Conference on Industrial Technology, pp. 696-701, Seville, 2015.

[2] Anand, S., and Fernandes, B.G., "Optimal Voltage Level for DC Microgrids”, IEEE 36th Annual Conference on Industrial Electronics Society, pp. 3034-3039, Glendale, 2010.

[3] Setthapun, W., Srikaew, S., Rakwichian, J., Tantranont, N., Rakwichian, W., and Singh, R., "The Integration and Transition to a DC Based Community: A Case study of the Smart Community in Chiang Mai World Green City”, IEEE $1^{\text {st }}$ International Conference on DC Microgrids, pp. 205-209, Atlanta, GA, 2015.

[4] Garbesi, K., Vossos, V., and Shen, H., "Catalog of DC Appliances and Power Systems”, Lawrence Berkeley National Lab, Berkeley, CA, 2011.

[5] Makarabbi, G., Gavade, V., Panguloori, R., and Mishra, P., "Compatibility and Performance Study of Home Appliances in a DC Home Distribution System”, IEEE International Conference on Power Electronics, Drives and Energy Systems, pp. 1-6, Mumbai, 2014. 
Matayoshi, H., Senjyu, T., and Funabashi, T., "Islanding Operation of DC Smart Grid under DC Distribution Line Faults”, International Symposium on Smart Electric Distribution Systems and Technologies, pp. 313-317, Vienna, 2015.

[7] Mackay, L., Ramirez-Elizondo, L., and Bauer, P., "DC Ready Devices - Is Redimensioning of the Rectification Components Necessary?”, 16th International Conference on Mechatronics-Mechatronika, pp. 1-5, Brno, 2014.

[8] Enrique, R.D., Juan, C.V., and Josep, M.G., "Intelligent DC Homes in Future Sustainable Energy Systems: When Efficiency and Intelligence Work Together”, IEEE Consumer Electronics Magazine, Volume 5, No. 1, pp. 74-80, January, 2016.

[9] Vagelis, V., Karina, G., and Hongxia, S., "Energy Savings from Direct-DC in US Residential Buildings”, Elsevier Transaction on Energy and Buildings, Volume 68, pp. 223-231, 2014.

[10] Soo, H.L., and Jung, W.P., "Optimal Operation of Multiple DGs in DC Distribution System to Improve System Efficiency”, IEEE Transactions on Industry Applications, No. 99, pp. 1-1, 21 June, 2016.

[11] Kamran, M., Bilal, M., Mudassar, M., and Shahid, M., "Techno-Economic Analysis of Distributed Generation for Microgrid Application Using HOMER Pro”, International Journal of Emerging Technology \& Advanced Engineering, Volume 5, No. 7, pp. 272-279, July, 2015.

[12] Laudani, G.A., and Paul, D.M., "Comparison of Cost and Efficiency of DC Versus AC in Office Buildings", Engineering and Physical Sciences Research Council, Imperial College London.

[13] Pang, H., Lo, E., and Pong, B., "DC Electrical Distribution Systems in Buildings”, 2nd International Conference on Power Electronics Systems and Applications, pp. 115-119, Hong Kong, 2006.

[14] Lin, B., "Electric Drive System with BLDC Motor", International Conference on Electric Information and Control Engineering, pp. 359-363,Wuhan, 2011.

[15] Saxena, A., "Performance and Cost Comparison of PM BLDC Motors for Ceiling Fan”, IEEE International Conference on Power Electronics, Drives and Energy Systems, pp. 1-5, Mumbai, 2014.

[16] "The HSAC Line of Solar or Wind Air Conditioners", Retrieved from [online] http://www.geinnovations.net/ solar_air_conditioner.html (June 05, 2016).
“12,000 BTU DC Air Conditioner For Off-Grid Solar \& Telecom Applications”, Hotspot Energy, Retrieved from [online] http://www.hotspotenergy.com/DC-airconditioner/. (June 05, 2016).

[18] "Standby Power Summary Table”, Lawrence Berkeley National Laboratory, Retrieved from [online] http:// standby.lbl.gov/summary-table. (June 17, 2016).

[19] Kreha, V., "CFLs vs. LEDs: The Better Bulbs”, Green America, Spring, 2010, Retriever from [online] http:// www.greenamerica.org/livinggreen/CFLs.cfm. (June 01, 2016).

[20] Shin, D.M., "Inverter Microwave Oven and Method for Controlling the same”, US Patent 7,064,306 B2, USA, June 20, 2006.

[21] "Solar Pumping System-Boreholes, Wells \& Irrigation”, Energy Development Co-operated Limited, Retrieved from [online] http://www.solar-wind.co.uk/solar-waterpumps-borehole-well-pumping-irrigation (June 05, 2016).

[22] Sathaye, N., Phadke, A., Shah, N., and Letschert, V., "Potential Global Benefits of Improved Ceiling Fan Energy Efficiency”, Lawrence Berkeley National Laboratory Report [eLBNL-5980E], 2012.

[23] Desroches, L,B., and Garbesi, K., "Max Tech and Beyond Maximizing Appliance and Equipment Efficiency by Design”, Lawrence Berkeley National Laboratory, Report [eLBNL-4998E], 2011.

[24] Rajan, K., Bhim, S., Ambrish, C., and Kamal, A., "Solar PV Array Fed Water Pumping Using BLDC Motor Drive with Boost-Buck Converter”, IEEE Energy Conversion Congress and Exposition, pp. 5741-5748, Montreal, QC, 2015.

[25] "LED 101: What is LED? What it Means for You, The Consumer!”, LBS Lightening (June 24, 2015), Retrieved from [online] https://www.lbclighting.com/blog/2015/ 06/led-101-what-is-led/. on June 01, 2016.

[26] "Electricity Usage of an LCD/LED Display or TV Screen”, Retrieved from [online] http:// energyusecalculator.com/index.html. (June 05, 2016).

[27] Load Value Calculator, http://www.skylab.org/ gelbardn/ studio/loadeval.pdf (June 22, 2016).

[28] Rasmussen, C.B., and Ritchie, E., "Variable Speed Brushless DC Motor Drive for Household Refrigerator Compressor", $8^{\text {th }}$ International Conference on Electrical Machines and Drives, pp. 128-132, Cambridge, 1997. 